\title{
Design and Irradiation of a Molten Salt Corrosion Experiment in The Ohio State University Research Reactor
}

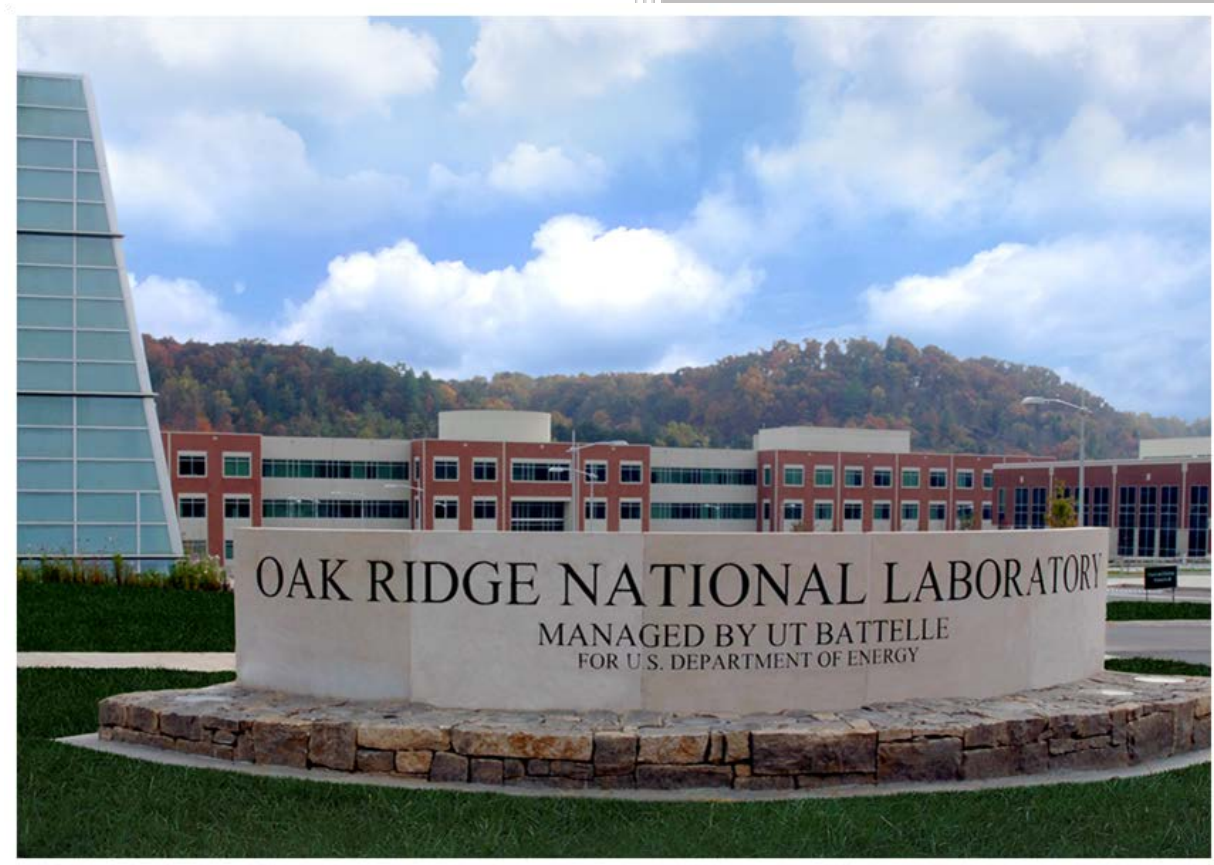

Approved for public release. Distribution is unlimited.

Joel McDuffee

N. Diane Bull Ezell

Kurt Smith

Stephen Raiman

Neil Taylor

Lou Qualls

September 2018 


\title{
DOCUMENT AVAILABILITY
}

Reports produced after January 1, 1996, are generally available free via US Department of Energy (DOE) SciTech Connect.

\section{Website www.osti.gov}

Reports produced before January 1, 1996, may be purchased by members of the public from the following source:

\author{
National Technical Information Service \\ 5285 Port Royal Road \\ Springfield, VA 22161 \\ Telephone 703-605-6000 (1-800-553-6847) \\ TDD 703-487-4639 \\ Fax 703-605-6900 \\ E-mail info@ntis.gov \\ Website http://classic.ntis.gov/
}

Reports are available to DOE employees, DOE contractors, Energy Technology Data Exchange representatives, and International Nuclear Information System representatives from the following source:

Office of Scientific and Technical Information

PO Box 62

Oak Ridge, TN 37831

Telephone 865-576-8401

Fax 865-576-5728

E-mail reports@osti.gov

Website http://www.osti.gov/contact.html

This report was prepared as an account of work sponsored by an agency of the United States Government. Neither the United States Government nor any agency thereof, nor any of their employees, makes any warranty, express or implied, or assumes any legal liability or responsibility for the accuracy, completeness, or usefulness of any information, apparatus, product, or process disclosed, or represents that its use would not infringe privately owned rights. Reference herein to any specific commercial product, process, or service by trade name, trademark, manufacturer, or otherwise, does not necessarily constitute or imply its endorsement, recommendation, or favoring by the United States Government or any agency thereof. The views and opinions of authors expressed herein do not necessarily state or reflect those of the United States Government or any agency thereof. 
Reactor and Nuclear Systems Division

Design and Irradiation of a Molten Salt Corrosion Experiment in The Ohio State University Research Reactor

\author{
Author(s) \\ Joel McDuffee \\ N. Diane Bull Ezell \\ Kurt Smith \\ Stephen Raiman \\ Neil Taylor \\ Lou Qualls
}

September 2018

Prepared by

OAK RIDGE NATIONAL LABORATORY

Oak Ridge, TN 37831-6283

managed by

UT-BATTELLE, LLC

for the

US DEPARTMENT OF ENERGY

under contract DE-AC05-00OR22725 



\section{CONTENTS}

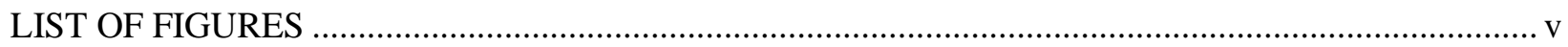

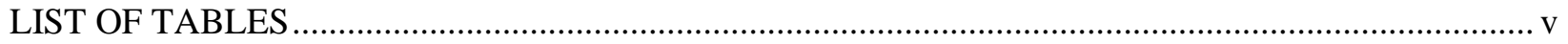

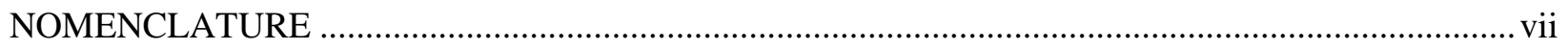

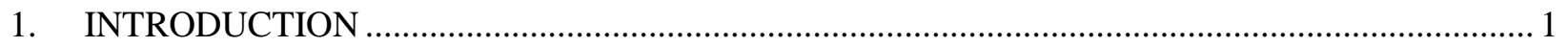

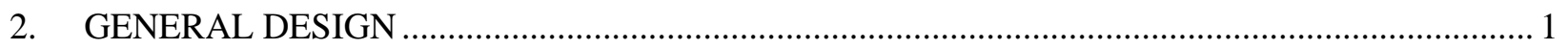

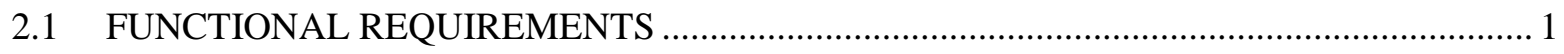

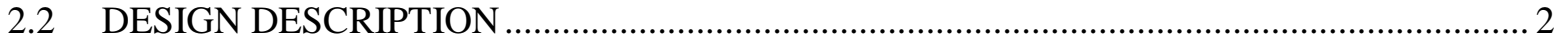

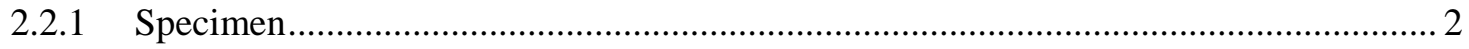

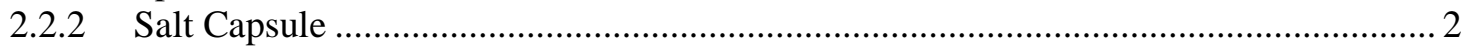

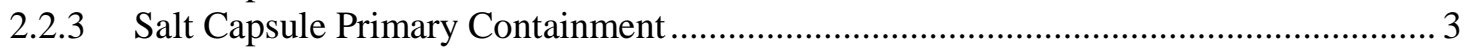

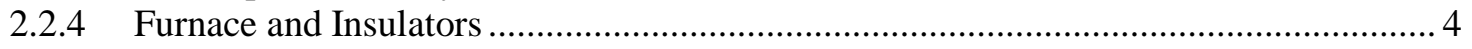

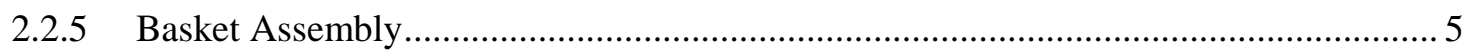

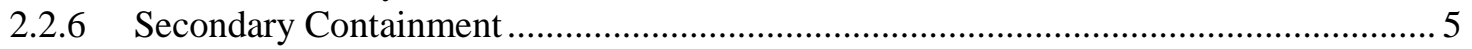

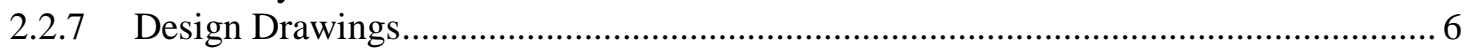

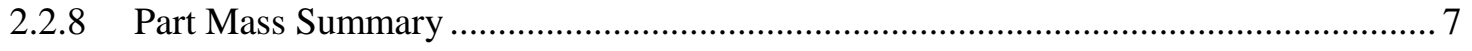

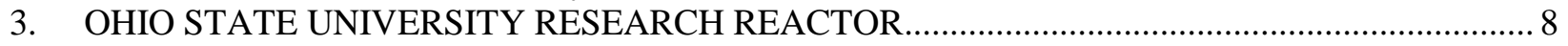

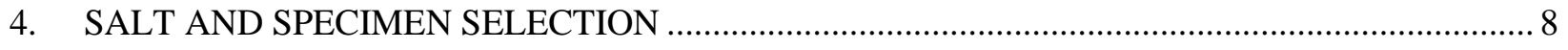

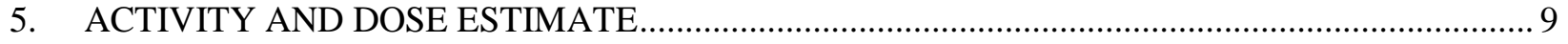

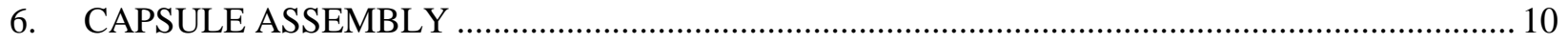

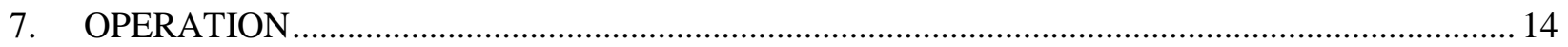

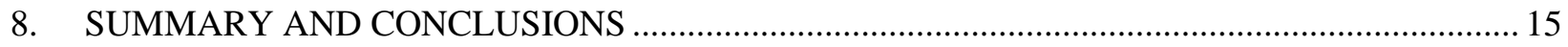

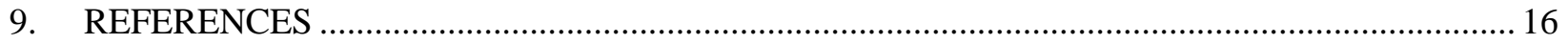





\section{LIST OF FIGURES}

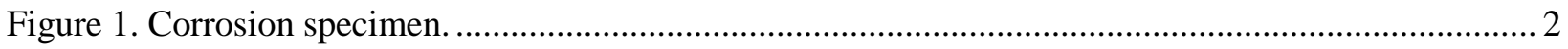

Figure 2. Salt container with salt and specimen............................................................................. 3

Figure 3. Primary containment assembly, shown (left) empty and (right) filled with four capsules............ 4

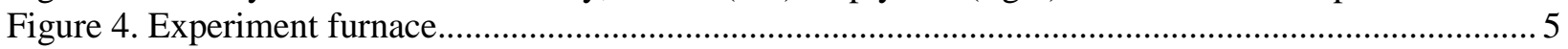

Figure 5. Secondary containment, shown (left) empty and (right) filled................................................. 6

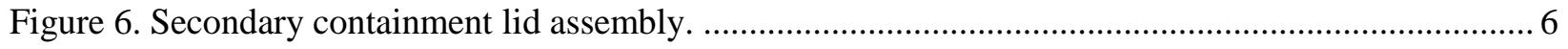

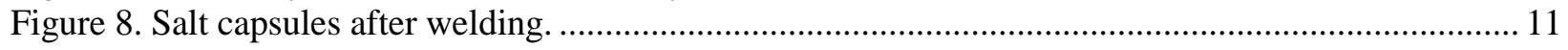

Figure 9. Primary containment assembly including vessels and peripheral parts..................................... 12

Figure 10. Results of radiography performed on the (left) secondary containment, (middle) capsule

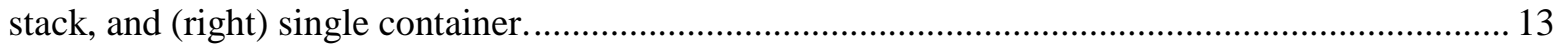

Figure 11. Final experiment assembly onsite at OSU........................................................................... 13

Figure 12. Experiment under irradiation at the OSURR........................................................................ 14

Figure 13. Experiment temperature profile overall operating days. ......................................................... 15

\section{LIST OF TABLES}

Table 1. Drawing list for the molten salt corrosion experiment .......................................................... 7

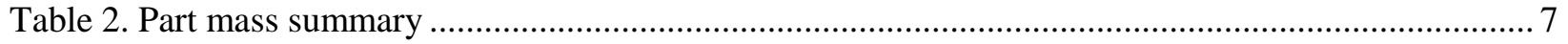

Table 3. Characteristics of selected irradiation positions in the OSURR ….............................................. 8

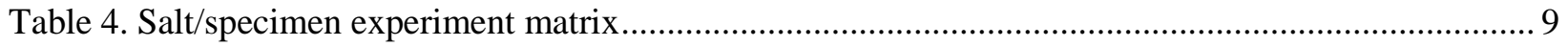

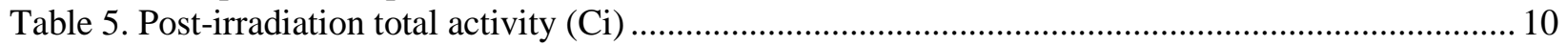

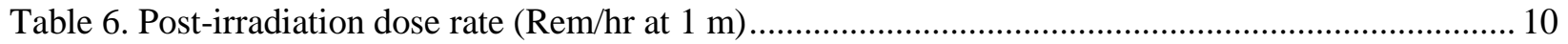





\section{NOMENCLATURE}

MCNP

MSR

ORNL

OSU

OSURR
Monte Carlo N-Particle code

molten salt reactor

Oak Ridge National Laboratory

The Ohio State University

Ohio State University Research Reactor 



\section{INTRODUCTION}

The primary containment system of any molten salt reactor (MSR) will be exposed to corrosive salt at high temperatures $\left(>650^{\circ} \mathrm{C}\right.$ )(McDuffee et al. 2018). Many MSR designs also use dissolved fuel, which introduces the challenge of fission product-induced corrosion. Even those designs that do not call for dissolved fuel might need to address the deleterious effects of dissolved fission products on the fuel containment system and potential particle failure.

The primary containment and all internal components should, for both design and safety purposes, (1) be resistant to salt corrosion, (2) maintain adequate strength under anticipated and off-normal conditions, and (3) be resistant to corrosion induced by entrained fission products. Some of these design issues can be managed without irradiation testing, but neutron-induced changes in structural materials and fission product-induced changes in the salt composition will inevitably modify the structural materials' behavior and can only be addressed with irradiation testing.

Irradiation testing in support of the MSR development will include a wide variety of experimental vehicles including static capsules, natural convection loops, and pumped loops under both low-flux and high-flux conditions. This document summarizes the design and irradiation of a low-flux, static capsule that was irradiated in the Ohio State University Research Reactor (OSURR) in 2018. The salt used for this experiment is a eutectic mixture of $\mathrm{KCl}-\mathrm{MgCl}_{2}$, which is a common composition for use as an out-ofcore coolant and should have corrosive properties similar to other chloride salts such as $\mathrm{NaCl}-\mathrm{MgCl}_{2}$. Two alloys were chosen for this study: Alloy N, a low-chromium nickel-base alloy developed for use with molten salts, and 316 stainless steel, a common candidate material for MSRs due to its extensive use in nuclear systems. An experimental temperature of $800^{\circ} \mathrm{C}$ was chosen to accelerate degradation during exposure.

\section{GENERAL DESIGN}

\subsection{FUNCTIONAL REQUIREMENTS}

This simple static capsule experiment required that the following key parameters and design conditions be met.

- Containment.-The salt and specimen should be contained in a weld-sealed capsule for the duration of the experiment and transport. No salt should be able to escape.

- $\quad$ Temperature.-The salt must be molten $\left(426^{\circ} \mathrm{C}\right)$ to create the conditions necessary to cause corrosion. It should be noted that some salts disassociate when irradiated at low temperature (Briggs 1964). The temperature should be controlled and measured for the entire irradiation period.

- Salt volume.-There should be a sufficient amount of salt in the experiment so that corrosion products do not significantly change the salt composition, which would affect the specimen's corrosion rate. The salt volumes and specimen surface area used for the current experiment were taken from successful out-of-pile corrosion experiments being conducted at Oak Ridge National Laboratory (ORNL).

- Materials.-Materials should be carefully selected to ensure compatibility with high-temperature salt. 


\subsection{DESIGN DESCRIPTION}

The experiment team took advantage of two key pieces of existing infrastructure to accelerate the testing program: (1) a proven molybdenum capsule successfully deployed under an ongoing corrosion testing program at ORNL, and (2) an existing furnace sized for the OSURR that can hold the existing molybdenum capsule without significant modification.

\subsubsection{Specimen}

The specimen to be held in the salt is a small rectangular shape measuring $6.4 \mathrm{~mm} \times 1.59 \mathrm{~mm} \times 12.7 \mathrm{~mm}$. Before assembly, the specimen is attached by a small wire to the molybdenum container end cap. Figure 1 shows how the specimen was attached to the end cap.

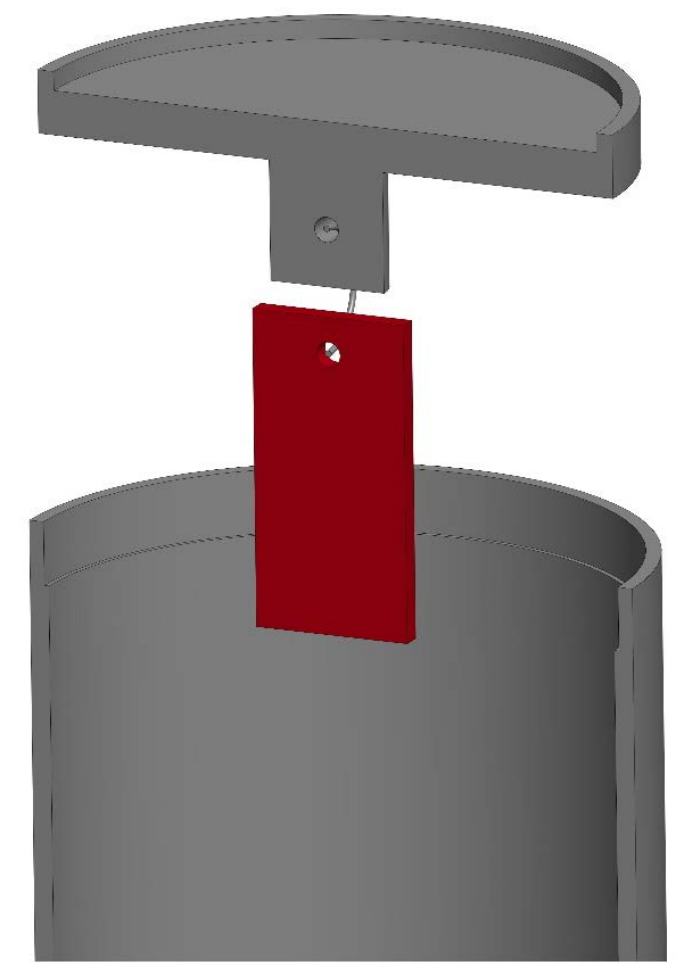

Figure 1. Corrosion specimen.

The nominal volumes for the specimen and wire were $127 \mathrm{~mm}^{3}$ and $2 \mathrm{~mm}^{3}$, respectively. The specimen mass depends on the material density, but assuming a density of $8 \mathrm{~g} / \mathrm{cm}^{3}$ (typical for stainless steel), the specimen mass was approximately $1 \mathrm{~g}$. The molybdenum wire mass was approximately $0.02 \mathrm{~g}$. The surface area of the specimen was approximately $112 \mathrm{~mm}^{2}$.

\subsubsection{Salt Capsule}

The salt capsule housing consists of a small molybdenum container that is open on both ends. A solid end cap is welded to one end of the capsule. The container is then filled with solid salt chunks. The specimen is attached to the opposite end cap with wire, and the end cap is circumferentially welded to the other end of the capsule under vacuum conditions. Figure 2 shows the completed capsule assembly. Note that during irradiation the capsule is inverted so that the specimen is immersed in the liquid salt. 
The volume of the housing and end caps is $6.36 \mathrm{~cm}^{3}$. All parts are molybdenum, which has a nominal density of $10.22 \mathrm{~g} / \mathrm{cm}^{3}$, so the resulting mass is $65.0 \mathrm{~g}$.

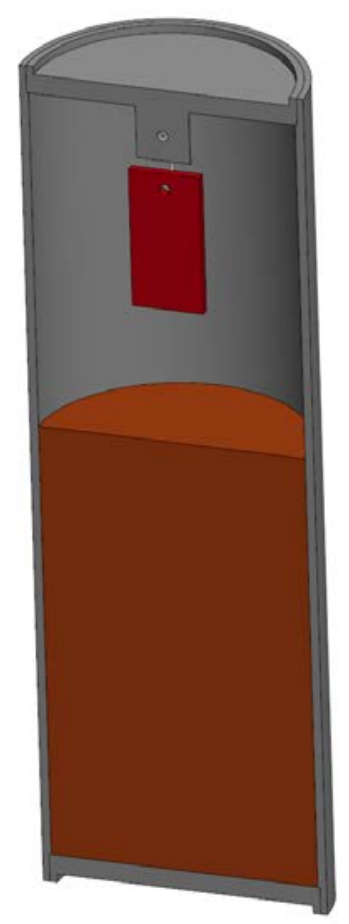

Figure 2. Salt container with salt and specimen.

\subsubsection{Salt Capsule Primary Containment}

Four capsule assemblies are stacked and loaded into the salt capsule primary containment. The assemblies consist of a simple titanium cylinder with a $50.8 \mathrm{~mm}$ outer diameter and $406 \mathrm{~mm}$ length fitted on each end with a plate that is $3.18 \mathrm{~mm}$ thick. The purpose of the primary containment is to provide a sealed environment with which to handle, move, irradiate, and ship the inner capsule assembly stack. Figure 3 shows the primary containment assembly, both with and without a capsule stack inserted. The capsule stack inside the primary containment is wrapped in Grafoil (not shown in Figure 3, but visible in the assembly pictures in Section 6), which serves as a diffusion buffer between the molybdenum and titanium and fills the gap between the stack and the containment to reduce mechanical interaction.

The combined volume of the cylinder and two end caps is $123.4 \mathrm{~cm}^{3}$. Titanium has a density of $4.43 \mathrm{~g} / \mathrm{cm}^{3}$, so the total mass is approximately $547 \mathrm{~g}$. 

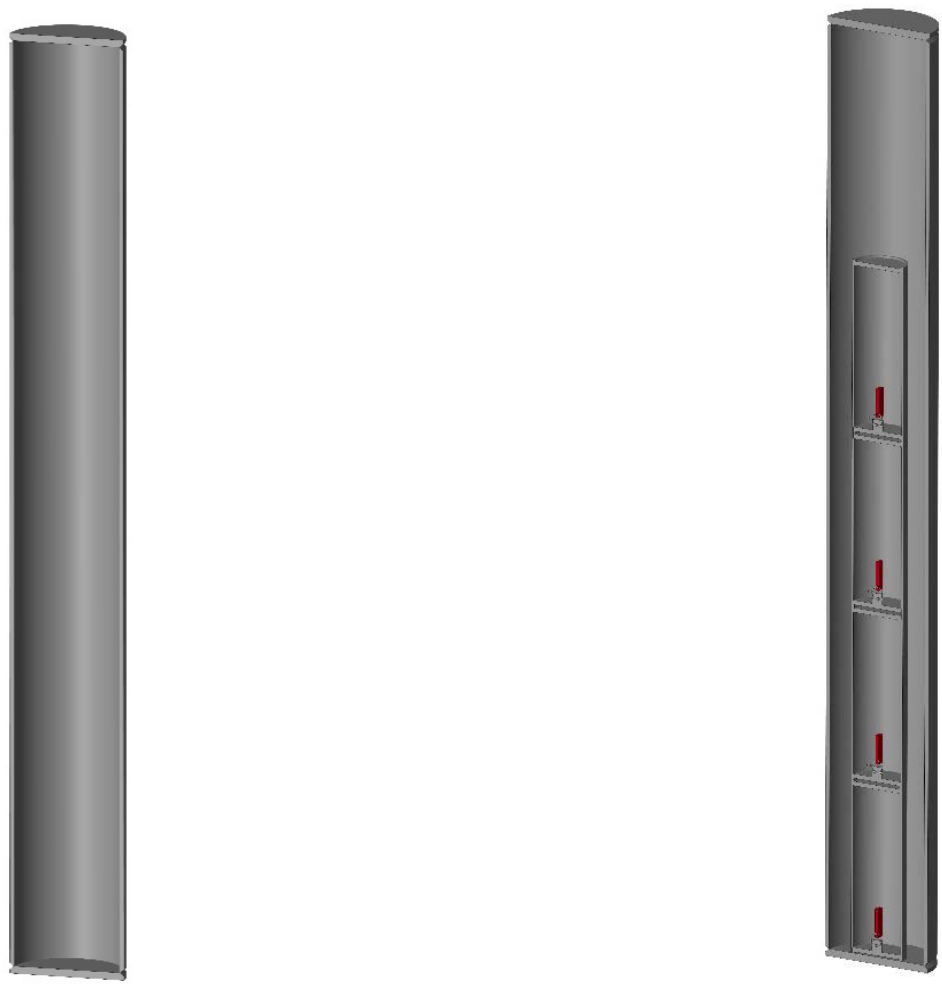

Figure 3. Primary containment assembly, shown (left) empty and (right) filled with four capsules.

\subsubsection{Furnace and Insulators}

This experiment used a Thermcraft VF-360-4-12-V-S furnace that has a $19.7 \mathrm{~cm}$ outer diameter and 53.34 $\mathrm{cm}$ height. The furnace uses a Kanthal A-1 Resistance wire coiled around the inner surface of the heated region. The insulation consists of Thermcraft 2300 vitreous aluminosilicate fibers (composition: 42\% alumina, $56 \%$ silica, $2 \%$ other). The heater operates at a maximum power of $1800 \mathrm{~W}$, a maximum voltage of $240 \mathrm{~V}$, and a maximum temperature of $1100^{\circ} \mathrm{C}$. The heated length is $45.7 \mathrm{~cm}$, and the heated inner diameter is $6.35 \mathrm{~cm}$. Figure 4 shows the furnace used in this experiment inside the basket (described in Section 2.2.5) and a view through the center hole. The furnace volume is $9809.9 \mathrm{~cm}^{3}$; its mass is $5.85 \mathrm{~kg}$.

The furnace is capped top and bottom with Thermcraft 2300 insulators. The top insulator has a volume of $1366.6 \mathrm{~cm}^{3}$ and a mass of $0.620 \mathrm{~kg}$. The bottom insulator has a volume of $1505.5 \mathrm{~cm}^{3}$ and a mass of $0.680 \mathrm{~kg}$. 

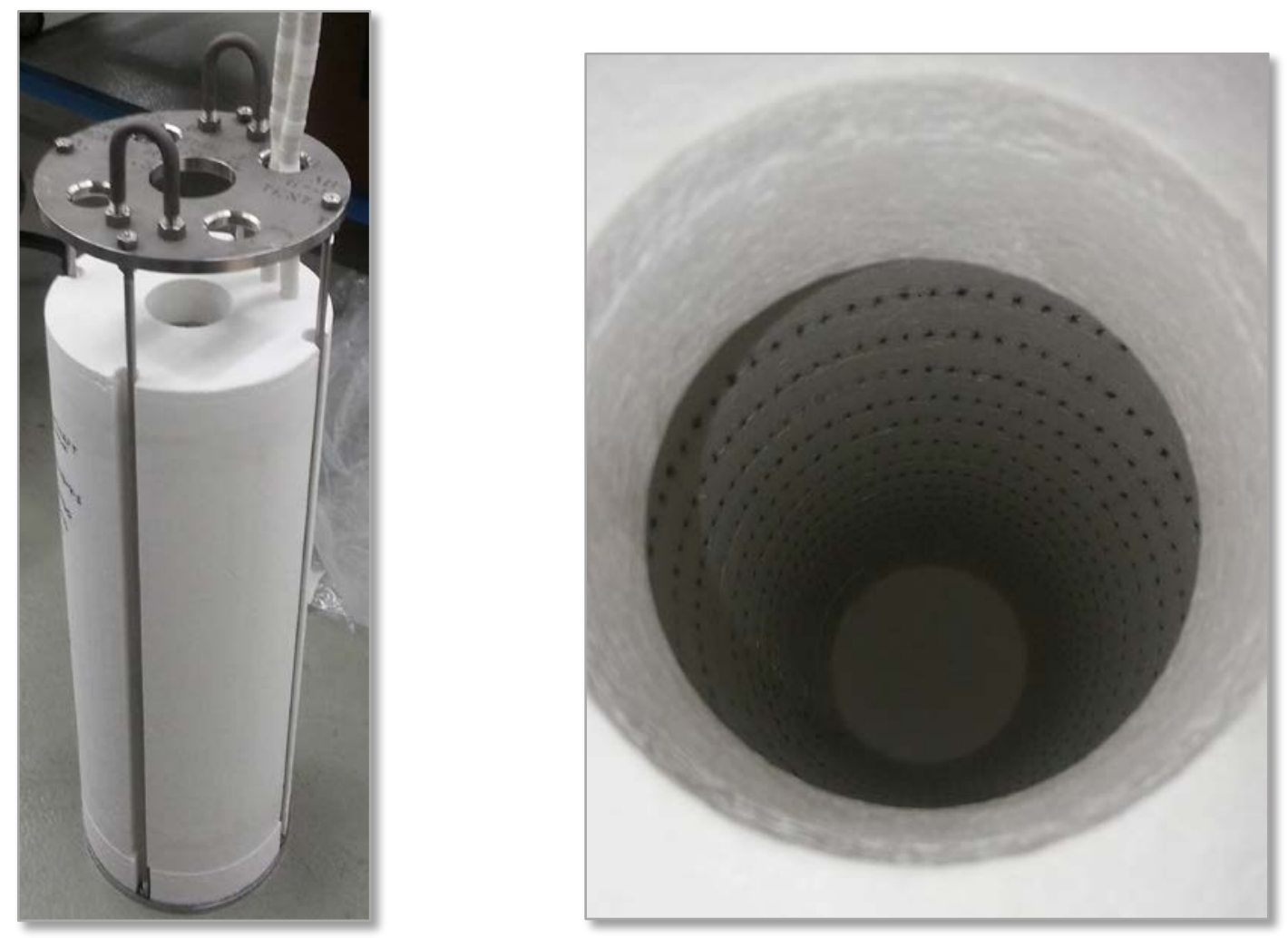

Figure 4. Experiment furnace.

\subsubsection{Basket Assembly}

The basket assembly — a metal framework with four tie rods (shown in Figure 4, left panel)—holds the experiment furnace and allows easy removal of all internal components from the secondary containment. The basket assembly is fabricated from grades 2 and 5 titanium alloys and has a total volume of 661.1 $\mathrm{cm}^{3}$. The assembly's total mass is $3.065 \mathrm{~kg}$.

\subsubsection{Secondary Containment}

The secondary containment includes an Al-6061 cylinder with a $228.6 \mathrm{~mm}$ outer diameter, $203.2 \mathrm{~mm}$ inner diameter, and $1532.5 \mathrm{~mm}$ length, as well as a solid Al-6061 lower end cap that is $15 \mathrm{~mm}$ thick. These two pieces together have a volume of $13.660 \mathrm{~cm}^{3}$ and a total mass of $36.88 \mathrm{~kg}$.

The upper lid assembly (see Figure 6) consists of a $6.4 \mathrm{~mm}$ thick stainless steel plate with a lifting lug welded to the top. Multiple pass-through holes in the lid allow for power, gas piping, and instrumentation. The lid assembly is attached to the main cylinder housing using 16 titanium 5/8 in. screws and sealed using a $3 / 32$ in. O-ring. 

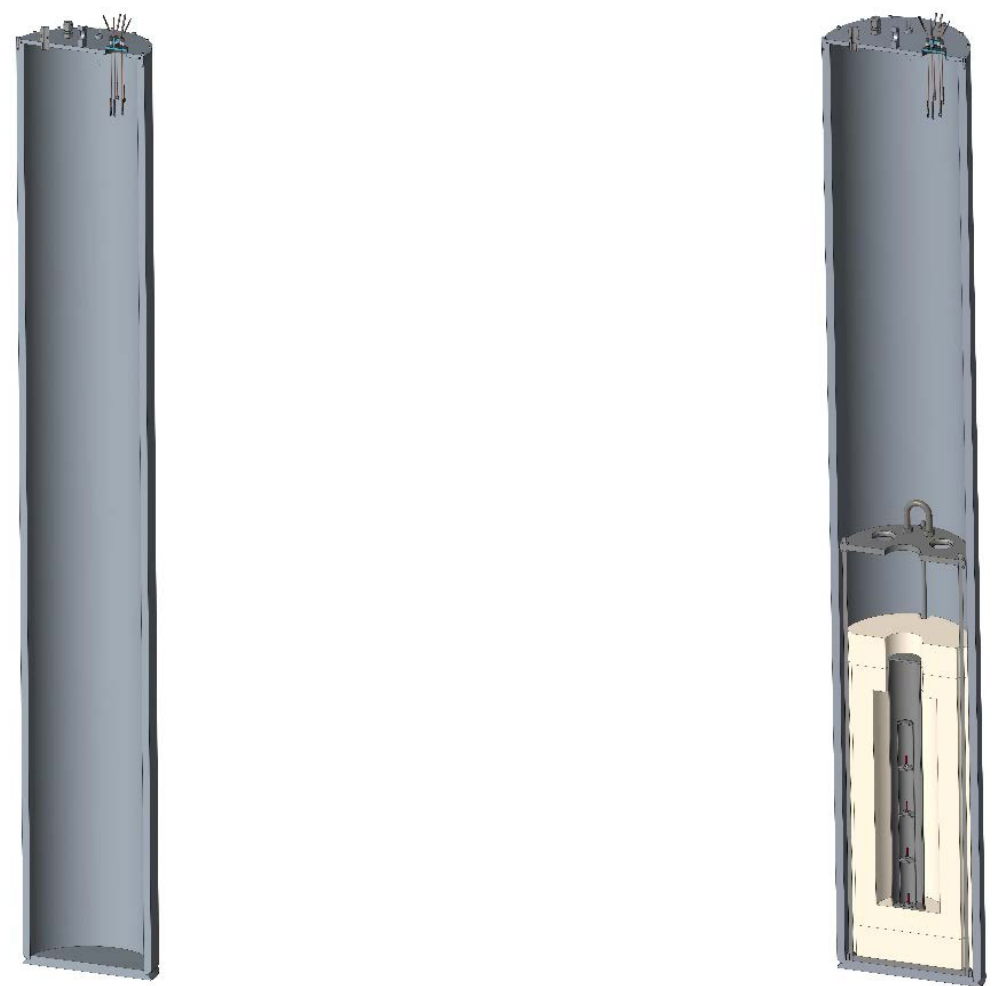

Figure 5. Secondary containment, shown (left) empty and (right) filled.

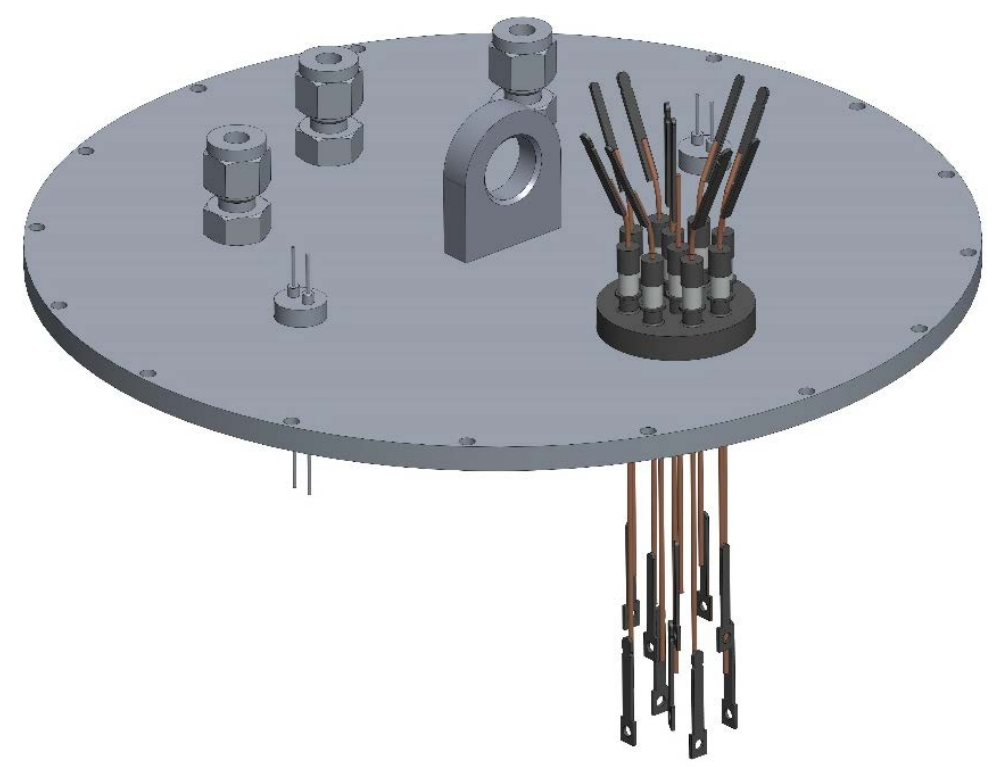

Figure 6. Secondary containment lid assembly.

The lid, lifting lug, tube fittings, and feedthroughs have a total volume of $274.06 \mathrm{~cm}^{3}$ and a mass of 2.192 $\mathrm{kg}$. The titanium screws each have a volume of $0.187 \mathrm{~cm}^{3}$ and a mass of $0.82 \mathrm{~g}$. All 16 screws have a total mass of $13.1 \mathrm{~g}$.

\subsubsection{Design Drawings}

Table 1 provides the complete drawing list for this experiment. 
Table 1. Drawing list for the molten salt corrosion experiment

\begin{tabular}{|c|c|c|}
\hline Drawing no. & Title & Includes \\
\hline S16-36-DETECTORB & $\begin{array}{l}\text { Secondary containment bottom } \\
\text { assembly }\end{array}$ & $\begin{array}{l}\text { Secondary containment bottom cap } \\
\text { Secondary containment tube } \\
\text { Secondary containment bottom assembly }\end{array}$ \\
\hline S16-37-DETECTORB & $\begin{array}{l}\text { Secondary containment lid } \\
\text { assembly }\end{array}$ & $\begin{array}{l}\text { Secondary containment lid assembly } \\
\text { Secondary containment lid plate } \\
\text { Lifting lug } \\
\text { Tube fittings } \\
\text { Power feedthroughs } \\
\text { Thermocouple feedthroughs }\end{array}$ \\
\hline S16-42-DETECTORB & Basket assembly & $\begin{array}{l}\text { Basket assembly } \\
\text { Basket rods } \\
\text { Basket bottom plate } \\
\text { Basket top plate } \\
\text { U-bolt } \\
\text { Hex nuts } \\
\end{array}$ \\
\hline S16-43-DETECTORB & Insulator disks & $\begin{array}{l}\text { Bottom cap } \\
\text { Top cap } \\
\text { Furnace bottom cap } \\
\text { Furnace top disk }\end{array}$ \\
\hline S18-05-SALT_CAP & $\begin{array}{l}\text { OSU salt capsule experiment } \\
\text { assembly }\end{array}$ & Salt capsule irradiation experiment \\
\hline S18-03-SALT_CAP & $\begin{array}{l}\text { OSU salt irradiation capsule part } \\
\text { details and assembly }\end{array}$ & $\begin{array}{l}\text { Salt irradiation capsule assembly } \\
\text { Salt capsule housing } \\
\text { Specimen } \\
\text { Top end cap } \\
\text { Perforated specimen holder } \\
\text { Salt } \\
\text { Wire }\end{array}$ \\
\hline S18-32-SALT_CAP & $\begin{array}{l}\text { OSU salt irradiation capsule } \\
\text { primary containment details }\end{array}$ & $\begin{array}{l}\text { Primary containment } \\
\text { Tube } \\
\text { End cap } \\
\text { Lifting lug }\end{array}$ \\
\hline
\end{tabular}

\subsubsection{Part Mass Summary}

Table 2 summarizes the parts used in the experiment and their respective masses. The total experiment mass is $50.23 \mathrm{~kg}(111 \mathrm{lbm})$.

Table 2. Part mass summary

\begin{tabular}{|l|l|c|c|c|}
\hline \multicolumn{1}{|c|}{ Part } & \multicolumn{1}{c|}{ Material } & $\begin{array}{c}\text { Part mass } \\
(\mathbf{g})\end{array}$ & $\begin{array}{c}\text { Experiment } \\
\text { count }\end{array}$ & Total mass (g) \\
\hline Specimen & Steel or nickel alloy & 1.00 & $3^{*}$ & 3.00 \\
\hline Wire & Molybdenum & 0.02 & $3^{*}$ & 0.06 \\
\hline Salt & KCl-MgCl & 30. & $3^{*}$ & 90. \\
\hline Salt Capsule Housing & Molybdenum & 65. & $3^{*}$ & 195. \\
\hline Primary Containment & Titanium alloy & 547. & 1 & 547. \\
\hline Salt container wrap & Grafoil & 94.71 & 1 & 94.71 \\
\hline Furnace & Alumina/silica & 5850. & 1 & 5850. \\
\hline Furnace insulators & Alumina/silica & 1300. & 1 & 1300. \\
\hline Basket assembly & Titanium alloy & 3065 & 1 & 3065 \\
\hline
\end{tabular}


Table 2. Part mass summary (continued)

\begin{tabular}{|c|c|c|c|c|}
\hline Part & Material & $\begin{array}{c}\text { Part mass } \\
\text { (g) }\end{array}$ & $\begin{array}{l}\text { Experiment } \\
\text { count }\end{array}$ & Total mass (g) \\
\hline Secondary containment & Al-6061 & 36,880 & 1 & 36900 \\
\hline Upper lid assembly & Stainless steel & 2192 & 1 & 2190 \\
\hline Lid assembly screws & Titanium alloy & 0.82 & 16 & 13.1 \\
\hline \multicolumn{4}{|c|}{ Experiment total } & 50,230 \\
\hline
\end{tabular}

* The design called for four capsules, but a weld failure during fabrication led to the removal of one of the capsules.

\section{OHIO STATE UNIVERSITY RESEARCH REACTOR}

The OSURR is a pool-type reactor located at The Ohio State University (OSU) in Columbus, Ohio. It is licensed to operate at a thermal power of up to $0.5 \mathrm{MW}$ with an active fueled length of $38 \mathrm{~cm}$. The OSURR is operated using an on-demand schedule. This makes it ideally suited to short-term irradiations.

Three irradiation positions are available within the core grid, with each consisting of a dry tube that extends from the top of the pool to a position in the core grid. Moveable vertical dry tubes with $17.8 \mathrm{~cm}$ and $25.4 \mathrm{~cm}$ outer diameters are available for placing experiments at or near the core boundary. Table 3 provides a summary of the size and neutron flux for these irradiation positions.

Table 3. Characteristics of selected irradiation positions in the OSURR

\begin{tabular}{|c|c|c|c|}
\hline Irradiation positions & $\begin{array}{c}\text { Inner } \\
\text { Diameter (cm) } \\
\end{array}$ & $\begin{array}{l}\text { Thermal flux } \\
\left(10^{13} \mathrm{n} / \mathrm{cm}^{2} \cdot \mathrm{s}\right) \\
\end{array}$ & $\begin{array}{c}\text { Fast flux (1 MeV eq. }) \\
\left(10^{13} \mathrm{n} / \mathrm{cm}^{2} \cdot \mathrm{s}\right)\end{array}$ \\
\hline Central Irradiation Facility & 3.30 & 1.4 & 0.47 \\
\hline Auxiliary Irradiation Facility & 6.22 & 0.45 & 0.26 \\
\hline Peripheral Irradiation Facility & 6.35 & 0.31 & 0.12 \\
\hline $17.8 \mathrm{~cm}$ dry tube & 16.51 & 0.11 & 0.02 \\
\hline $25.4 \mathrm{~cm}$ dry tube & 24.13 & 0.081 & 0.016 \\
\hline
\end{tabular}

The $25.4 \mathrm{~cm}$ diameter dry tube was chosen as the irradiation position for this experiment. The large diameter allows for larger-scale experiments. The relatively low neutron flux is not conducive to highfluence experiments but may be an ideal test bed for assessing cartridge loop technology in a facility more easily accessible than a national laboratory facility. The OSURR can accept fueled salt, but their postirradiation handling limits may restrict the fuel loading and burnup to relatively low levels (The Ohio State University College of Engineering 2018). Although licensed to operate at $500 \mathrm{kWth}$, experiments in the $25.4 \mathrm{~cm}$ diameter dry tube are limited to reactor power below $250 \mathrm{kWth}$ due to radiation streaming up the tube and limited shielding used at the pool top.

\section{SALT AND SPECIMEN SELECTION}

The salt used for this experiment is a eutectic mixture of $\mathrm{KCl}-\mathrm{MgCl}_{2}$ in a $68: 32$ molar ratio. This is a common composition for use as an out-of-core coolant and should have corrosive properties similar to other chloride salts such as $\mathrm{NaCl}-\mathrm{MgCl}_{2}$. Due to the short duration of exposure, an aggressive salt containing $\sim 1 \% \mathrm{H}_{2} \mathrm{O}$ was chosen to maximize the severity of attack during the limited exposure to ensure measurable alloy degradation. However, if the effect of irradiation is small, it is possible that the effect of impurity-based corrosion will overwhelm the effect of irradiation on alloy degradation. For this reason, a second, less aggressive salt containing $<30 \mathrm{ppm}_{2} \mathrm{O}$ was also chosen. 
Two alloys were chosen for this study: Alloy N, a low-chromium nickel-base alloy developed for use with molten salts, and 316 stainless steel, a common candidate material for MSRs due to its extensive use in nuclear systems. An experimental temperature of $800^{\circ} \mathrm{C}$ was chosen to accelerate degradation during exposure. Table 4 provides the experimental matrix. Half of the samples were separated for irradiation, and the other half will receive the same temperature treatment without irradiation.

Table 4. Salt/specimen experiment matrix

\begin{tabular}{|c|l|c|c|c|c|}
\hline Capsule ID & \multicolumn{1}{|c|}{ Sample ID } & $\mathbf{H}_{2} \mathbf{O}$ impurity & Salt weight (g) & Specimen & Irradiated? \\
\hline 1 & OSU-6-D-I & $\sim 1 \%$ & 30.05 & 316 SS & YES \\
\hline 2 & OSU-N-D-I & $\sim 1 \%$ & 29.99 & Hastelloy N & YES \\
\hline 3 & OSU-6-D-U & $\sim 1 \%$ & 29.96 & 316 SS & NO \\
\hline 4 & OSU-N-D-U & $\sim 1 \%$ & 30.06 & Hastelloy N & NO \\
\hline 5 & OSU-6-C-I & $<30 \mathrm{ppm}$ & 30.02 & 316 SS & YES \\
\hline 7 & OSU-6-C-U & $<30 \mathrm{ppm}$ & 30.06 & $316 \mathrm{SS}$ & NO \\
\hline
\end{tabular}

Note: SS=stainless steel

\section{ACTIVITY AND DOSE ESTIMATE}

An activation analysis of the experiment was conducted to determine when the experiment could be handled and ultimately shipped back to ORNL. The activation analysis was completed using the ORIGEN code within the SCALE software package (Oak Ridge National Laboratory 2011). ORIGEN calculates the activation products (including mass and activity) after irradiation with user-specified mass, composition, neutron flux energy spectrum, irradiation time, and decay time. Monte Carlo N-Particle code (MCNP) (X-5 Monte Carlo Team 2003) simulations were performed using a model of the OSURR to determine the neutron flux energy spectrum in the $25.4 \mathrm{~cm}$ dry tube. The ORIGEN simulations were completed for 3 days of irradiation at a reactor power of $250 \mathrm{~kW}$ and 7 hours of irradiation per day.

Decay time between successive days of irradiation was included in the simulations, as was additional decay time after the third day of irradiation. The atomic masses of the individual experimental components were input into the ORIGEN code in two separate categories. The salt capsules, salt, and specimens were categorized together, while the rest of the components were analyzed separately. These groupings were created such that an appropriate shipping date for the salt capsules could be determined. All components except for the lid of the secondary containment were assumed to receive the centerline total neutron flux value of $7.12 \cdot 10^{11} \mathrm{n} / \mathrm{cm}^{2} / \mathrm{s}$ within the dry tube for $250 \mathrm{~kW}$ reactor power. The secondary containment lid, which sits roughly $1.2 \mathrm{~m}$ above the core centerline, received a neutron flux of 5.87·10 $\mathrm{n} / \mathrm{cm}^{2} / \mathrm{sec}$ based on MCNP calculations using a model of the OSURR core.

Table 5 presents the results of the activation analysis, using 238 group cross sections from ENDF/B-VII.1 (Brookhaven National Laboratory 2018) and JEFF-3.0/A (Nuclear Energy Agency 2018). The activity for each element was output by ORIGEN. The activities were then used to calculate the gamma dose rate for the experiment using gamma ray dose conversion factors (Unger and Trubey 1982) as shown in Table 6. The dominant activity and dose contribution of the salt capsules results from ${ }^{51} \mathrm{Cr}$, ${ }^{99} \mathrm{Mo}$, and ${ }^{99 \mathrm{~m}} \mathrm{Te}$. The dominant activity and dose contribution of the supporting experimental components results from ${ }^{51} \mathrm{Cr}$, ${ }^{59} \mathrm{Fe}$, and ${ }^{65} \mathrm{Zn}$. An initial large activity and dose immediately follow irradiation due to ${ }^{28} \mathrm{Al}$ produced in the secondary containment, but decays quickly with a half-life of $2.2 \mathrm{~min}$. 
Table 5. Post-irradiation total activity (Ci)

\begin{tabular}{|c|c|c|c|}
\hline Activity & Other components & Salt capsule and specimens & Total \\
\hline Day 1 irradiation & $1.99 \mathrm{E}+03$ & $2.63 \mathrm{E}+01$ & $2.02 \mathrm{E}+03$ \\
\hline Decay & $6.90 \mathrm{E}+00$ & $6.06 \mathrm{E}-01$ & $7.51 \mathrm{E}+00$ \\
\hline Day 2 irradiation & $2.00 \mathrm{E}+03$ & $2.68 \mathrm{E}+01$ & $2.02 \mathrm{E}+03$ \\
\hline Decay & $8.70 \mathrm{E}+00$ & $8.70 \mathrm{E}-01$ & $9.57 \mathrm{E}+00$ \\
\hline
\end{tabular}

Table 5. Post-irradiation total activity (Ci) (continued)

\begin{tabular}{|c|c|c|c|}
\hline Activity & Other components & Salt capsule and specimens & Total \\
\hline Day 3 irradiation & $2.00 \mathrm{E}+03$ & $2.70 \mathrm{E}+01$ & $2.02 \mathrm{E}+03$ \\
\hline Day 4 morning & $9.32 \mathrm{E}+00$ & $1.01 \mathrm{E}+00$ & $1.03 \mathrm{E}+01$ \\
\hline Day 5 morning & $2.71 \mathrm{E}+00$ & $4.90 \mathrm{E}-01$ & $3.20 \mathrm{E}+00$ \\
\hline Day 6 morning & $1.12 \mathrm{E}+00$ & $2.88 \mathrm{E}-01$ & $1.40 \mathrm{E}+00$ \\
\hline Day 7 morning & $6.70 \mathrm{E}-01$ & $1.99 \mathrm{E}-01$ & $8.69 \mathrm{E}-01$ \\
\hline Day 8 morning & $5.38 \mathrm{E}-01$ & $1.52 \mathrm{E}-01$ & $6.91 \mathrm{E}-01$ \\
\hline
\end{tabular}

Table 6 shows that, on the morning of Day 8, the experiment was within OSU's handling limits for tool manipulation (dose rate of $100 \mathrm{mrem} / \mathrm{hr}$ at $1 \mathrm{~m}$ ). The salt capsule experiment remained in the dry tube for four full weeks following irradiation. The experiment was then relocated to another temporary storage location for one day before being re-packaged and shipped back to ORNL.

Table 6. Post-irradiation dose rate (Rem/hr at $1 \mathrm{~m})$

\begin{tabular}{|c|c|c|c|}
\hline Activity & Other components & Salt capsule and specimens & Total \\
\hline Day 1 irradiation & $1.72 \mathrm{E}+03$ & $1.86 \mathrm{E}+01$ & $1.74 \mathrm{E}+03$ \\
\hline Decay & $1.91 \mathrm{E}+00$ & $9.39 \mathrm{E}-01$ & $2.84 \mathrm{E}+00$ \\
\hline Day 2 irradiation & $1.72 \mathrm{E}+03$ & $1.92 \mathrm{E}+01$ & $1.74 \mathrm{E}+03$ \\
\hline Decay & $2.26 \mathrm{E}+00$ & $1.26 \mathrm{E}+00$ & $3.51 \mathrm{E}+00$ \\
\hline Day 3 irradiation & $1.73 \mathrm{E}+03$ & $1.95 \mathrm{E}+01$ & $1.74 \mathrm{E}+03$ \\
\hline Day 4 morning & $2.37 \mathrm{E}+00$ & $1.37 \mathrm{E}+00$ & $3.73 \mathrm{E}+00$ \\
\hline Day 5 morning & $4.98 \mathrm{E}-01$ & $4.66 \mathrm{E}-01$ & $9.64 \mathrm{E}-01$ \\
\hline Day 6 morning & $1.61 \mathrm{E}-01$ & $1.66 \mathrm{E}-01$ & $3.27 \mathrm{E}-01$ \\
\hline Day 7 morning & $6.14 \mathrm{E}-02$ & $6.42 \mathrm{E}-02$ & $1.26 \mathrm{E}-01$ \\
\hline Day 8 morning & $3.12 \mathrm{E}-02$ & $2.86 \mathrm{E}-02$ & $5.97 \mathrm{E}-02$ \\
\hline
\end{tabular}

\section{CAPSULE ASSEMBLY}

As described in Section 4, each molybdenum container was filled with approximately $30 \mathrm{~g}$ of solid salt in a glove box and then seal-welded in a vacuum. Figure 7 shows the three seal-welded containers selected for irradiation. 


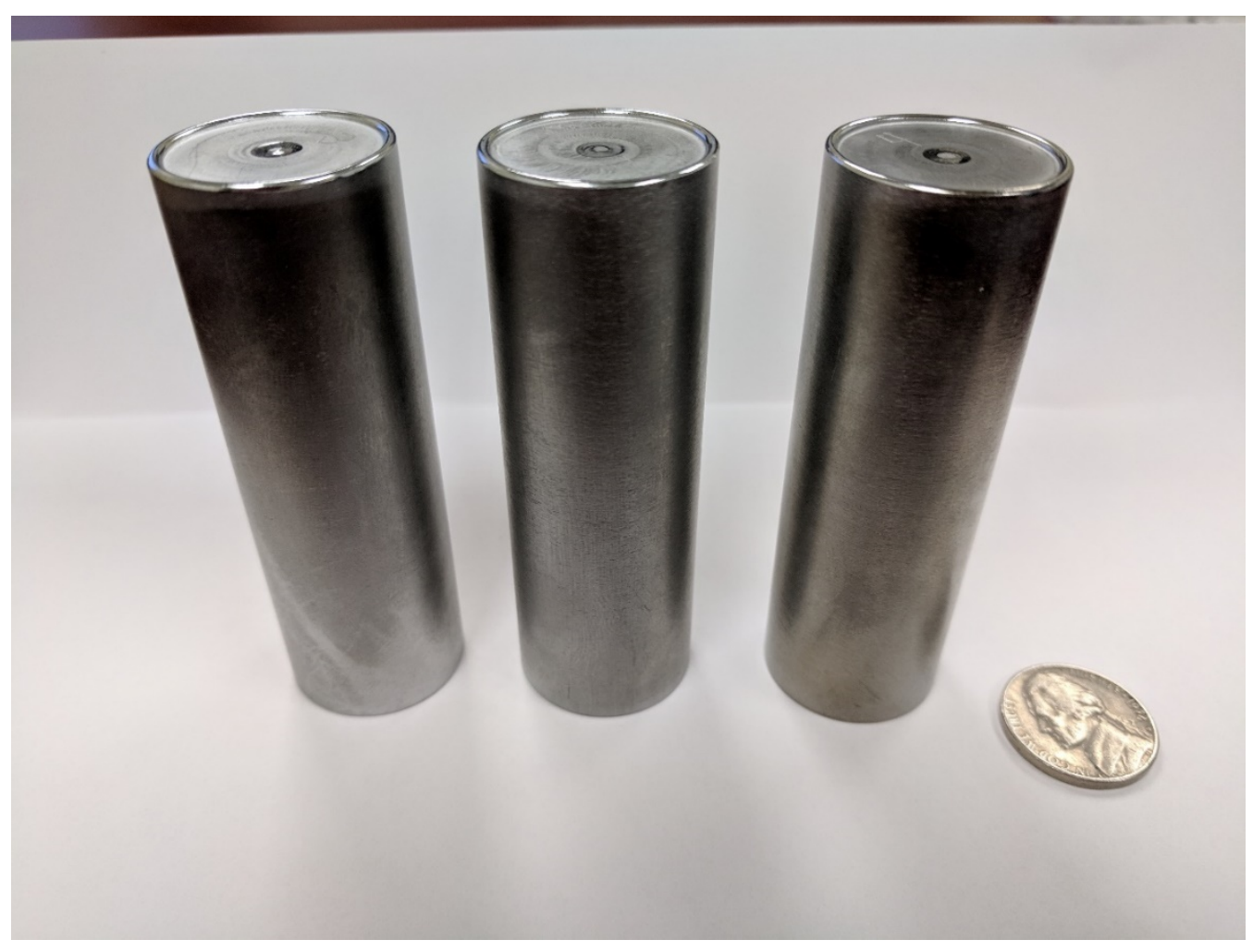

Figure 7. Salt capsules after welding.

Figure 8 shows the layout of the three capsules, along with the primary containment vessel and peripheral parts. The capsule stack is wrapped in Grafoil, which serves as a diffusion buffer between the molybdenum and titanium and fills the gap between the stack and the containment to reduce mechanical interaction. 


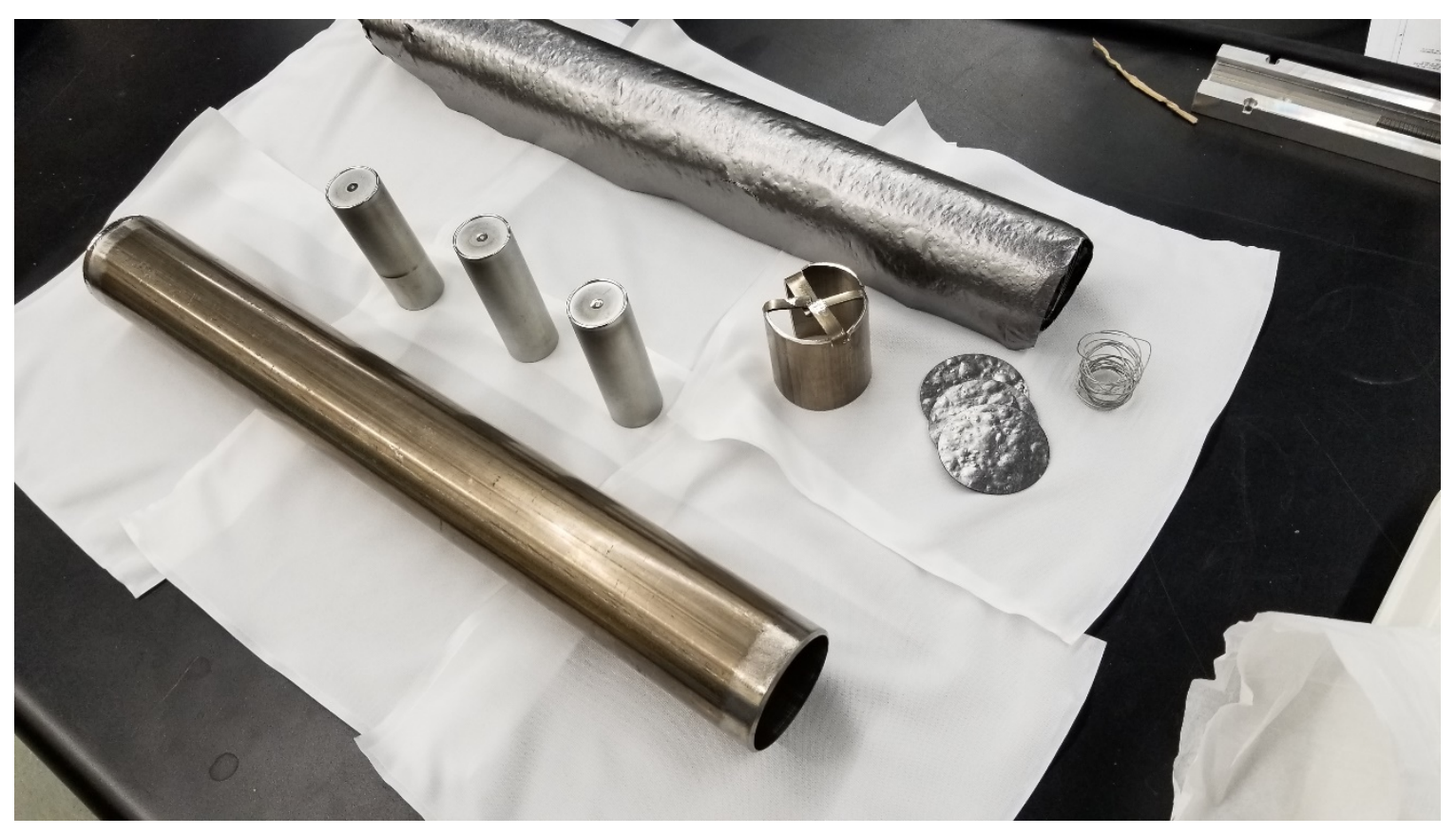

Figure 8. Primary containment assembly including vessels and peripheral parts.

After welding in argon and conducting a weld inspection, the primary containment assembly was leak tested and radiographed. Figure 9 shows the results of radiography performed on the primary containment post-welding to ensure that the capsule stack was located properly. The salt density is too low to be seen, but the molybdenum capsules, end cap, and specimens are clearly visible. Note that the capsule stack was inverted from that shown in the radiograph.

After welding and weld qualification of the primary containment, three thermocouples were welded to the side of the primary containment, as shown in Figure 10. 

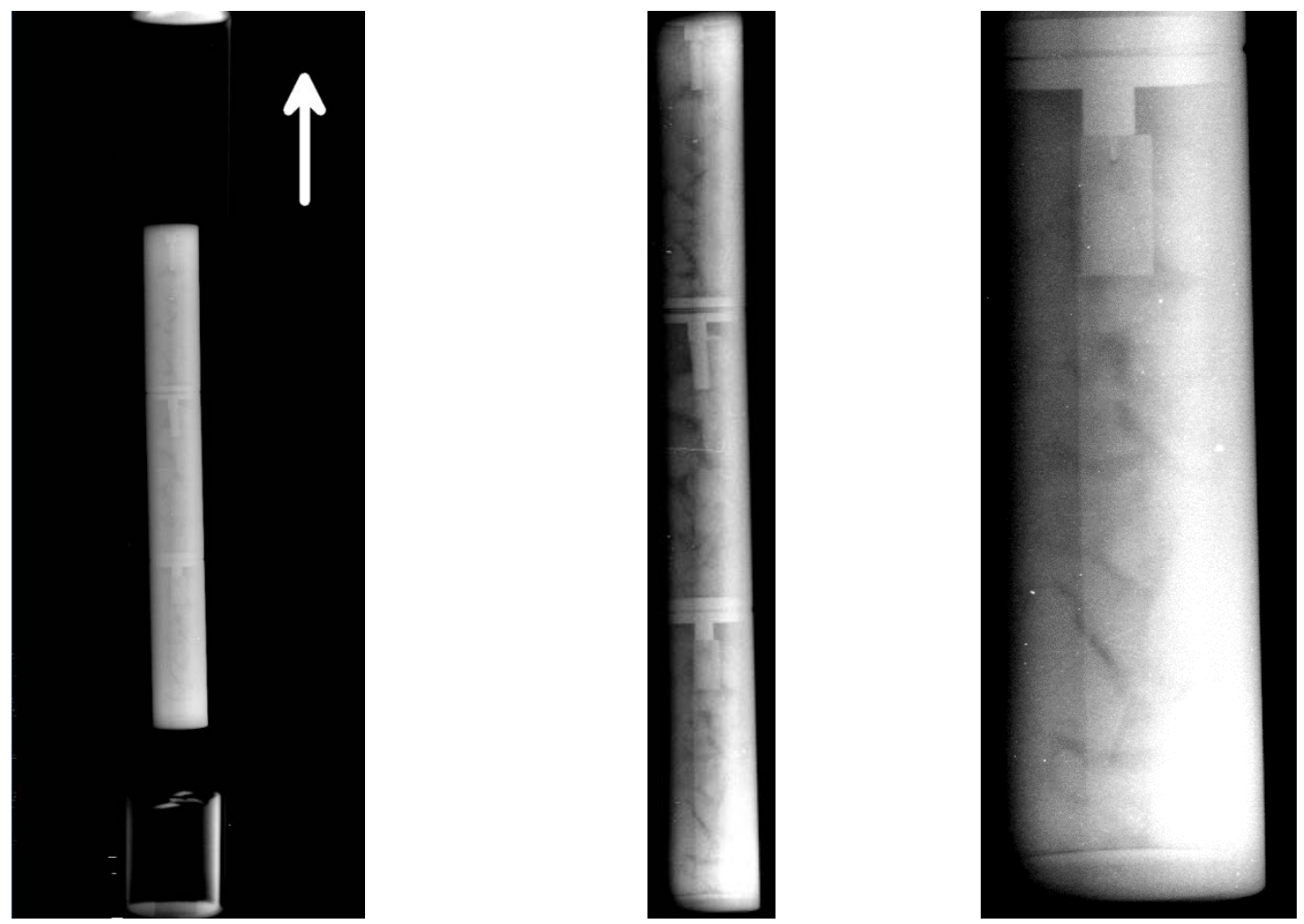

Figure 9. Results of radiography performed on the (left) secondary containment, (middle) capsule stack, and (right) single container.

At OSU, the primary containment, with thermocouples attached, was placed into the furnace and then into the secondary containment. The major pieces to the assembly are shown in the left panel of Figure 10. The secondary containment was then put under vacuum and filled with argon (middle panel). Once purged, the entire assembly was placed into the $25.4 \mathrm{~cm}$ dry tube in the reactor (right panel).
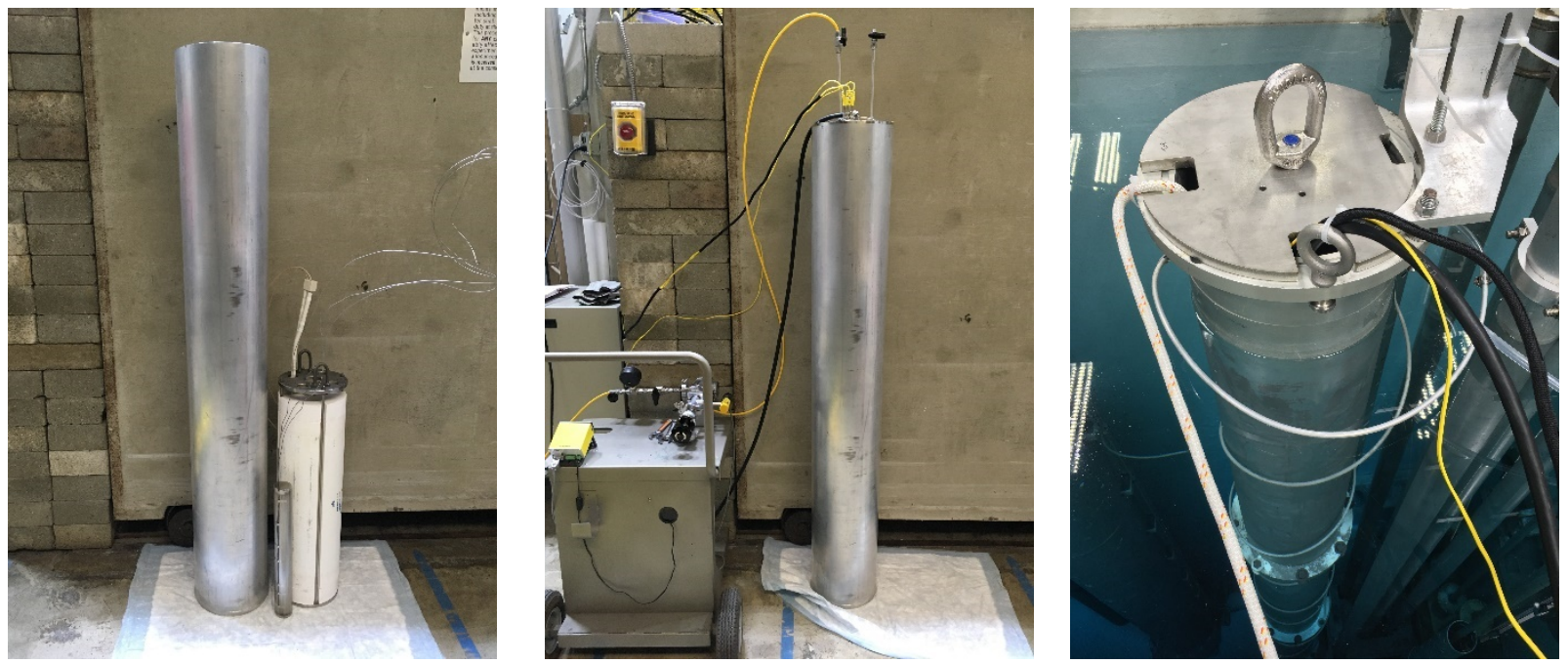

Figure 10. Final experiment assembly onsite at OSU. 


\section{OPERATION}

The OSURR began withdrawing control rods at 7:37 a.m. on Tuesday, August 14, 2018, and reached 250 $\mathrm{kW}$ at 8:42 a.m. The reactor shut down for the day at 3:42 p.m. after 7 hours of continuous operation. The reactor followed a similar pattern over the next 2 days, operating for a total of $6,000 \mathrm{~kW}$. Before each day's ascent to $250 \mathrm{~kW}$, the experiment was brought to a steady-state temperature of $800^{\circ} \mathrm{C}$, as measured by the three thermocouples attached to the primary containment's outer surface. Figure 11 shows the experiment loaded in the dry tube under irradiation. Figure 12 shows the combined temperature profile for the 3 operating days.

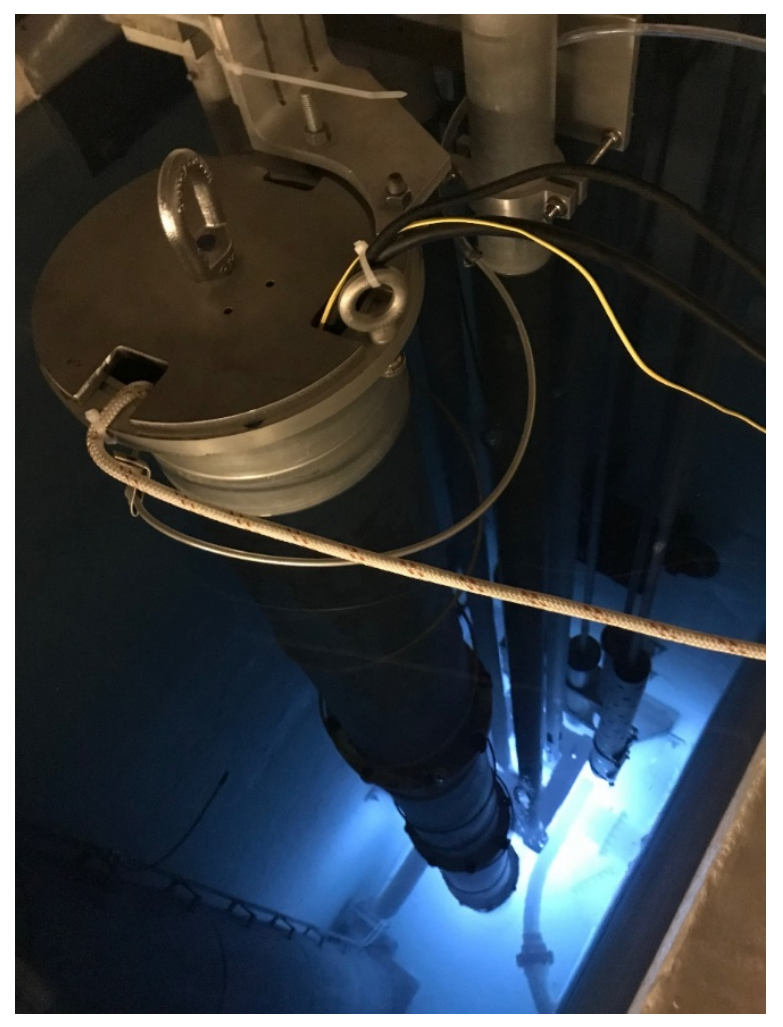

Figure 11. Experiment under irradiation at the OSURR. 


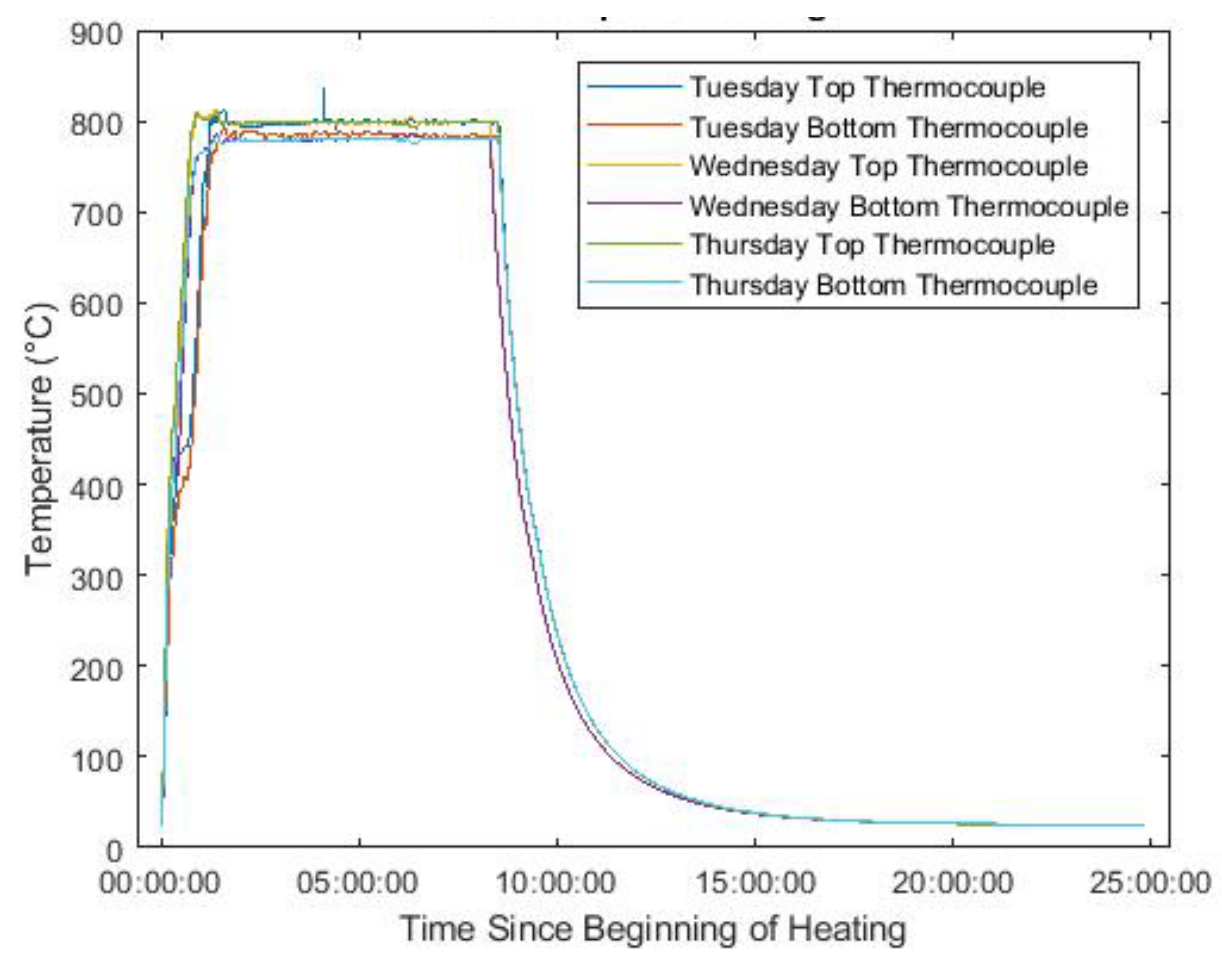

Figure 12. Experiment temperature profile overall operating days.

\section{SUMMARY AND CONCLUSIONS}

This report summarizes the design and irradiation of a low-neutron-flux, static capsule irradiated at the OSURR in 2018. A eutectic salt mixture of $\mathrm{KCl}-\mathrm{MgCl}_{2}$ in a 68:32 molar ratio was placed in each of three molybdenum capsules, along with either an Alloy $\mathrm{N}$ or 316 stainless steel specimen. Due to the short duration of exposure, an aggressive salt containing $\sim 1 \% \mathrm{H}_{2} \mathrm{O}$ was chosen for two capsules to maximize the severity of attack during the limited exposure time. A less aggressive salt containing $<30 \mathrm{ppm}_{2} \mathrm{O}$ was used in the remaining capsule. All three capsules were irradiated at $800^{\circ} \mathrm{C}$ for a total of $6,000 \mathrm{~kW} \mathrm{~h}$. The experiment has been shipped back to ORNL, and the specimens will be evaluated in fiscal year 2019. 


\section{REFERENCES}

Briggs, R.B. (d). 1964. Molten-salt Reactor Program Semiannual Progress Report for Period Ending July 31, 1964. Oak Ridge, TN, USA: Oak Ridge National Laboratory.

Brookhaven National Laboratory. 2018. National Nuclear Data Center Evaluated Nuclear Data File.

McDuffee, Joel L., Nesrin Ozgan Cetiner, N. Dianne Bull Ezell, A. Lou Qualls, and Ken R. Thoms. 2018. Evaluation of Flowing Salt Irradiation Facilities with High Neutron Flux. Oak Ridge National Laboratory.

Nuclear Energy Agency. 2018. Joint Evaluated Fission and Fusion (JEFF) Nuclear Data Library

Oak Ridge National Laboratory. 2011. SCALE: A Comprehensive Modeling and Simulation Suite for Nuclear Safety Analysis and Design. Oak Ridge, Tennessee, USA.

The Ohio State University College of Engineering. 2018. "Nuclear Reactor Laboratory." https://reactor.osu.edu/.

Unger, Laurie M., and D. K. Trubey. 1982. Specific Gamma-Ray Dose Constants For Nuclides Important to Dosimetry and Radiological Assessment. ORNL/RSIC-45/R1. Oak Ridge, Tennessee, U.S.A: Oak Ridge National Laboratory.

X-5 Monte Carlo Team. 2003. A General Monte Carlo N-Particle Transport Code, Version 5. LA-CP-030245. 